\title{
Nerocila sp. (Isopoda: Cymothoidae) parasitizing Mugil liza (Teleostei: Mugilidae) in São Francisco do Sul, Santa Catarina, Brazil
}

\author{
Juliano Santos Gueretz ${ }^{1}$ \\ Lucas Cardoso ${ }^{2}$ \\ Maurício Laterça Martins ${ }^{2}$ \\ Antonio Pereira de Souza ${ }^{1}$ \\ ${ }^{1}$ Instituto Federal Catarinense, Campus Araquari \\ Rodovia BR 280, km 27, CEP 89.245-000 Araquari - SC, Brasil \\ ${ }^{2}$ Laboratório AQUOS - Sanidade de Organismos Aquáticos \\ Universidade Federal de Santa Catarina, Florianópolis - SC, Brasil \\ * Autor para correspondência \\ juliano.gueretz@ifc.edu.br
}

Submetido em 04/08/2017

Aceito para publicação em 21/11/2017

\section{Resumo}

Nerocila sp. (Isopoda: Cymothoidae) parasite of Mugil liza (Teleostei: Mugilidae) capturado em São Francisco do Sul, estado de Santa Catarina, Brasil. Isópodes da família Cymothoidae são ectoparasitos de peixes, com baixa especificidade de hospedeiros, comumente encontrados fixados nas brânquias, boca, cavidade opercular, narinas e tegumento de ampla variedade de hospedeiros. Os danos causados são variáveis em função do grau de parasitismo e do sítio de infestação e podem provocar desconforto respiratório nos hospedeiros. O objetivo deste estudo foi relatar a ocorrência do isópode Nerocila sp. Leach, 1818 parasitando Mugil liza Valenciennes, 1836, capturada na Baía da Babitonga, estado de Santa Catarina, Brasil. Uma fêmea de $24 \mathrm{~mm}$ de comprimento e $11 \mathrm{~mm}$ de largura contendo ovos de $1.18 \pm 0.08 \times 1.03 \pm 0.06 \mathrm{~mm}$, foi encontrada na nadadeira peitoral de M. liza.

Palavras-chave: Baía da Babitonga; Crustáceo; Parasito; Tainha

\section{Abstract}

Isopods from the family Cymothoidae are fish ectoparasites displaying low host specificity found commonly attached to the gills, mouth, opercular cavity, nostrils and body surface of several host species. Damage can vary according to the degree of parasitism and the infestation site and may provoke respiratory discomfort in hosts. The aim of this study was to report the occurrence of a Nerocila sp. Leach, 1818 isopod parasitizing Mugil liza Valenciennes, 1836 captured in the Babitonga Bay, Santa Catarina State, Brazil. The female parasite specimen was recovered from the pectoral fin of M. liza and was $24 \mathrm{~mm}$ in length and $11 \mathrm{~mm}$ in width, and the mean egg size was $1.18 \pm 0.08 \times 1.03 \pm 0.06 \mathrm{~mm}$.

Key words: Babitonga Bay; Crustacean; Mullet; Parasite 
The Isopoda are dorsoventrally flattened crustaceans inhabiting both marine and freshwater environments (RAMESHKUMAR et al., 2016). Some isopod species play important roles in food webs by participating in the decomposition of material in natural or altered environments (ESPINOSA-PÉREZ; HENDRICKX, 2001; WILSON, 2008). Other species may act as ectoparasites of fish, usually parasitizing the gills, mouth, opercular cavity, nostrils and body surface of hosts (BOWMAN; TAREEN, 1983; CHARFICHEIKHROUHA et al., 2000; RAMDANE et al., 2007).

Nerocila spp. can be highlighted as one of the species from Cymothoidae (Leach, 1818) and is among the parasitic isopods (BRUSCA et al., 2001). They possess prehensile pereopods through their powerful curved claws and highly modified buccal parts that help them to remain attached to their hosts (THATCHER, 2006). They are also temporary and obligatory parasites and display low host specificity (ESPINOSA-PÉREZ; HENDRICKX, 2001; SMIT et al., 2014). The Cymothoidae life cycle is protandric and monoxenic (involving just one host) with direct transmission and sexual dimorphism (LEONARDOS; TRILLES, 2003; HIRANO et al., 2006); they are bloodfeeding organisms, but can also feed on body surface mucus as well as epithelial and subcutaneous host tissues (RAMDANE et al., 2007).

Host damage can vary according to the degree of parasitism and infestation site and ranges from light to severe damage with hemorrhage and tissue destruction. In general, severe damage can result in secondary infections. One of the main problems associated with parasitism is the repugnant appearance of infested fish, because parasites can be seen by the naked eye; this can cause significant economic losses to fisheries (EIRAS, 2004; LIMA et al., 2013; EIRAS; CASTRO, 2016).

The mullet Mugil liza is a widely distributed species and an important fisheries resource. They are traditionally exploited by inshore fishing and have been incorporated into various cultural events. Their bodies are elongated and fusiform, and notable morphological characteristics include the display of dark longitudinal striae alternating with white striae. They are detritivorous, pelagic and catadromous fish that form large schools during reproductive migrations (SECKENDORFF; AZEVEDO, 2007; MENEZES et al., 2010).

Bruce (1987), Ramdane et al. (2007), Öktener et al. (2010), Kayiş and Ceylan (2011), Al-Zubaidy and Mhaisen (2013), Mahmoud et al. (2016), describe the occurrence of Nerocila in mugilids, but they do not mention $M$. liza as hosts. In this study we report the occurrence of the isopod Nerocila sp. parasitizing specimen of M. liza captured in Babitonga Bay, Santa Catarina, Brazil.

One male mullet specimen measuring $41 \mathrm{~cm}$ in total length, $38.4 \mathrm{~cm}$ standard length and with a weight of 983 g was captured in March 2016 by a fisherman using a net in Babitonga Bay (26²' 50.0”S, 48 39'00.2”'W) in the São Francisco do Sul municipality, Santa Catarina State, Brazil. The parasite was found attached to the right pectoral fin of the fish (Figure 1) and was removed and placed in alcohol 70 for posterior identification according to Bruce (1987), Trilles (1975) and Brusca (1981). The host was identified according to Menezes et al. (2010; 2015).

The female isopod measured $24 \mathrm{~mm}$ long and 11 $\mathrm{mm}$ wide and was identified as Nerocila sp. (Figure 2) harboring $1.18 \pm 0.08 \times 1.03 \pm 0.06 \mathrm{~mm}$ sized eggs.

As the present report, Nerocila sp. has been reported parasitizing various teleost fish from Australia, New Zeland, Red Sea, France, Mediterranean Sea, Atlantic and North Ocean (BOWMAN; TAREEN, 1983; ÖKTENER et al., 2010; ABDEL-LATIF, 2016; YOUNES et al., 2016). Nerocila spp. have also been reported in Chondrichthyes fish, including sharks (MOREIRA; SADOWSKY, 1978). In Brazil, Nerocila fluviatilis Schiödte and Meinert, 1881 was reported by Sartor (1986) on the continental shelf of the state of Rio Grande do Sul, and Nerocila armata Dana, 1853 was reported in the states of São Paulo, Rio de Janeiro and Rio Grande do Sul (PIRES-VANIN, 1998; EIRAS; CASTRO, 2016). On the other hand, N. armata has been reported in the gill chamber and mouth of Cichla ocellaris (Bloch \& Schneider, 1801), Crenicichla saxatilis (Linnaeus, 1758), Leporinus fasciatus (Bloch, 1794), Mustelus canis (Mitchill, 1815), Micropogonias furnieri (Desmarest 1823), Pogonias cromis (Linnaeus, 
FIGURE 1: Nerocila sp. parasitizing the fin of Mugil liza (Valenciennes, 1836).

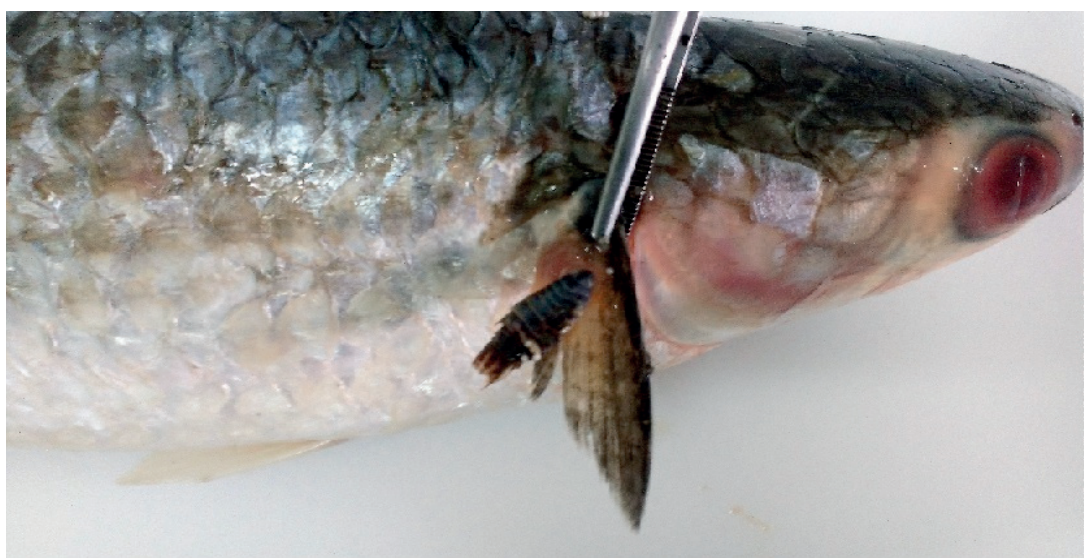

FIGURE 2: Female Nerocila sp. (Leach, 1818) parasite specimen on Mugil liza (Valenciennes, 1836) (A - dorsal view; B - ventral view; $\mathrm{C}$ - uropod; D - eggs).

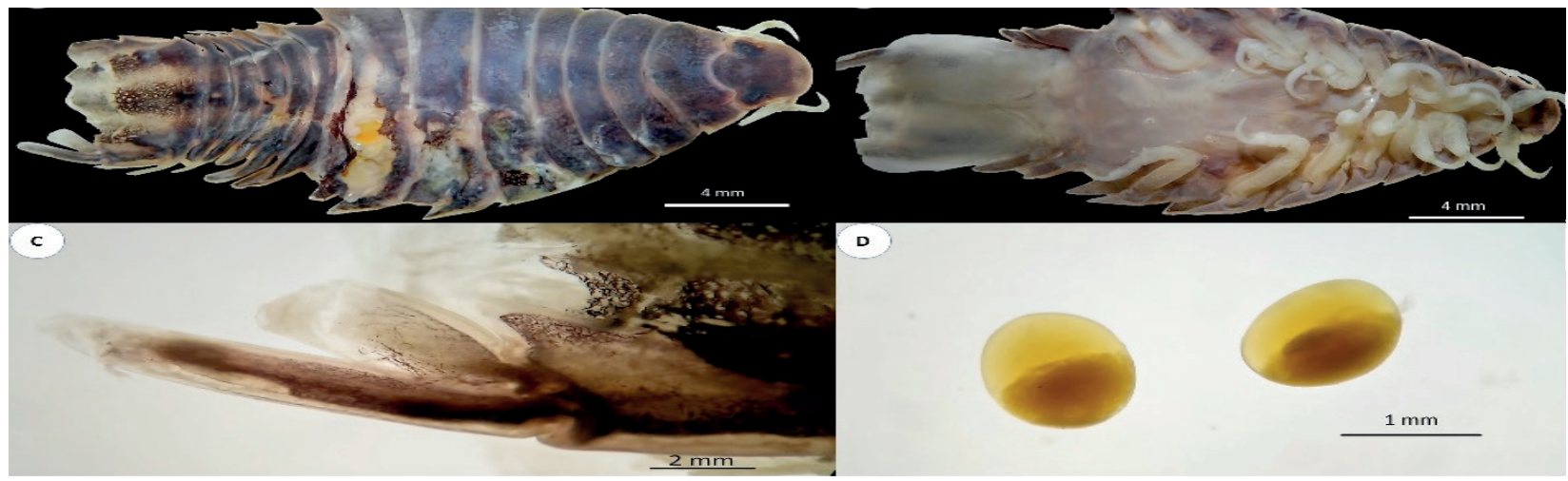

1766) and Pseudauchenipterus nodosus (Bloch, 1794) from Rio de Janeiro, Rio Grande do Sul and São Paulo (LUQUE et al., 2013); however, this species has not been reported on M. liza until the present study.

Using subaquatic pictures, Öktener et al. (2010) studied Nerocila parasites in mugilid fish from the Aegean and Black Seas. According to Bruce (1987), Al-Zubaidy and Mhaisen (2013) and Ramdane et al. (2007), Nerocila occurs mostly in Mugilidae fish, which corroborates results from the current study on the mullet M. liza.

This is the first report of Nerocila sp. on a mullet from southern Brazil. Additional studies are needed to elucidate the patterns of parasitism by these isopods on M. liza and other mullets, mainly for evaluating their potential to cause economic damage.

\section{Acknowledgements}

The authors thank the Brazilian National Council for Scientific and Technological Development $(\mathrm{CNPq}$ 305869/2014-0) for the grant to M. L. Martins.

\section{References}

ABDEL-LATIF, H. M. R. Cymothoid parasite, Nerocila orbigni [sic] inflicts great losses on Tilapia ziilli in Lake Qarun at ElFayoum Province. International Journal of Innovative Studies in Aquatic Biology and Fisheries, Ongole, v. 2, n. 3, p. 1-9, 2016. AL-ZUBAIDY, A. B.; MHAISEN, F. T. The first record of three cymothoid isopods from Red Sea fishes, Yemeni Coastal Waters. International Journal of Marine Science, Richmond, v. 3, n. 21, p. 166-172, 2013.

BOWMAN, T. E.; TAREEN I. U. Cymothoidae from fishes of Kuwait (Arabian Gulf) (Crustacea: Isopoda). Smithsonian Contributions to Zoology, Washington, v. 382, p. 1-30, 1983.

BRUCE, N. L. Australian species of Nerocila Leach, 1818, and 
Creniola n.gen. (Isopoda: Cymothoidae), crustacean parasites of marine fishes. Records of the Australian Museum, Sidney, v. 39, n. 6, p. 355-412, 1987.

BRUSCA, R. C. A monograph on the Isopoda Cymothoidae (Crustacea) of the eastern Pacific. Zoological Journal of the Linnean Society, London, v. 73, p. 117-199, 1981.

BRUSCA, R. C.; COELHO, V.; TAITI, S. A guide to the coastal isopods of California. Tree of Life Web Project. 2001. Disponível em: <http://tolweb.org/notes/?note_id=3004>. Acesso em: 20 jun. 2017.

CHARFI-CHEIKHROUHA, F.; ZGHIDI, W.; OULDYARBA, L.; TRILLES, J. P. Les Cymothoidae (Isopodes parasites de poissons) des côtes tunisiennes: ecologie et indices parasitologiques. Systematic Parasitology, The Hague, v. 46, n. 2, p. 143-150, 2000.

EIRAS, J. C. Aspectos gerais da patologia das parasitoses de peixes marinhos. In: RANZANI-PAIVA, M. J. T. (Ed.). Sanidade de organismos aquáticos. São Paulo: Varela, 2004. p. 143-156.

EIRAS, J. C.; CASTRO, R. Crustacea. In: EIRAS, J. C., VELLOSO, A. L.; PEREIRA Jr, J. (Ed.). Parasitos de peixes marinhos da América do Sul. Rio Grande: Ed. da FURG, 2016. p. 285-359.

ESPINOSA-PÉREZ, M. C.; HENDRICKX, M. E. Checklist of isopods (Crustacea: Peracarida: Isopoda) from the Eastern Tropical Pacific. Archive Belgian Journal of Zoology, Brussels, v. 131, n. 1, p. 43-55, 2001.

HIRANO, L. Q. L.; BOSSO, A. C. S.; VIEIRA, L. G.; BRITO, F. M. M.; PEREIRA, H. C.; SILVA JÚNIOR, L. M.; SILVA, J. M. M.; PEREIRA, P. C.; SANTOS, A. L. Q. Análise qualitativa e quantitativa de ectoparasitas de Pygocentrus nattereri Kner, 1860 (Characiformes: Characidae) da bacia do rio Araguaia, GO. Biológico, São Paulo, v. 68, p. 358-360, 2006.

KAYIŞ, Ş.; CEYLAN, Y. First report of Nerocila orbigyni (Crustacea, Isopoda, Cymothoidae) on Solea solea (Teleostei, Soleidae) from Turkish Sea. Turkish Journal of Fisheries and Aquatic Sciences, Trabzon, v. 11, p. 167-169, 2011.

LEONARDOS, I.; TRILLES, J. P. Host-parasite relationships: occurrence and effect of the parasitic isopod Mothocya epimerica on sand smelt Atherina boyeri in the Mesolongi and Etolikon Lagoons (W. Greece). Diseases of Aquatic Organisms, Oldendorf, v. 54, n. 3, p. 243-251, 2003.

LIMA, F. S.; CASALI, G. P.; TAKEMOTO, R. M. Crustacea. In: PAVANELLI, G. C.; TAKEMOTO, R. M.; EIRAS, J. C. (Org.). Parasitologia de peixes de água doce do Brasil. Maringá: Eduem, 2013. p. 371-397.

LUQUE, J. L.; VIEIRA, F. M.; TAKEMOTO, R. M.; PAVANELLI, G. C.; EIRAS, J. C. Checklist of Crustacea parasitizing fishes from Brazil. Check List, Rio Claro, v. 9, n. 6, p. 1449-1470, 2013.

MAHMOUD, N. E.; FAHMY, M. M.; ABUOWARDA, M. M.; KHATTAB, M. S. Parasitic cymothoid isopods and their impacts in commercially important fishes from Lake Qarun, Egypt. International Journal of Chem Tech Research, Mumbai, v. 9, n. 12, p. 221-229, 2016.

MENEZES, N. A.; NIRCHIO, M.; OLIVEIRA, C.; SICHRAMIREZ, R. Taxonomic review of the species of Mugil (Teleostei: Perciformes: Mugilidae) from the Atlantic South Caribbean and South America, with integration of morphological, cytogenetic and molecular data. Zootaxa, Auckland, v. 3918, n. 1, p. 1-38, 2015.
MENEZES, N. A.; OLIVEIRA, C.; NIRCHIO, M. An old taxonomic dilemma: the identity of the western south Atlantic lebranche mullet (Teleostei: Perciformes: Mugilidae). Zootaxa, Auckland, v. 2519, p. 59-68, 2010.

MOREIRA, P. S.; SADOSWSKY, V. An annotated bibliography of parasitic Isopoda (Crustacea) of Chondrichthyes. Boletim do Instituto Oceanográfico, São Paulo, v. 27, n. 2, p. 95-152, 1978.

ÖKTENER, A.; TORCU-KOÇ, H.; ERDOĞAN, Z.; TRILLES, J. P. Scuba diving photography: a useful method for taxonomic and ecologic studies on fish parasites (Cymothoidae). Journal of Marine Animals and Their Ecology, Ontario, v. 3, n. 2, p. 3-9, 2010.

PIRES-VANIN, A. M. S. Malacostraca - Peracarida. Marine Isopoda. Anthuridea, Asellota (pars), Flabellifera (pars), and Valvifera. In: YOUNG, P. S. (Ed.). Catalogue of Crustacea of Brazil. Rio de Janeiro: Museu Nacional, 1998. p. 605-624.

RAMDANE, Z.; BENSOUILAH, M. A.; TRILleS, J. P. The Cymothoidae (Crustacea, Isopoda), parasites on marine fishes, from Algerian fauna. Archive Belgian Journal of Zoology, Brussels, v. 137, n. 1, 67-74, 2007.

RAMESHKUMAR, G.; RAMESH, M.; RAVICHANDRAN, S.; TRILLES, J. P. Two Nerocila species parasitizing Pomadasys maculatus from Nagapattinam, Southeast coast of India. Journal of Parasitic Diseases, New Delhi, v. 40, n. 3, p. 968-970, 2016.

SARTOR, S. M. Incidência de isópodes parasitas (Cymothoidae) em peixes da plataforma continental brasileira. Boletim do Instituto Oceanográfico, São Paulo, v. 34, p. 1-12, 1986.

SECKENDORFF, R. W. von; AZEVEDO, V. G. de. Abordagem histórica da pesca da tainha Mugil platanus e do parati Mugil curema (Perciformes: Mugilidae) no litoral norte do estado de São Paulo. Instituto de Pesca, Série Relatórios Técnicos, São Paulo, n. 28, p. 1-8, 2007.

SMIT, N. J.; BRUCE, N. L; HADFIELD, K. A. Global diversity of fish parasitic isopod crustaceans of the family Cymothoidae. International Journal for Parasitology: Parasites and Wildlife, Amsterdam, v. 3, p. 188-197, 2014.

THATCHER, V. E. Amazon fish parasites. 2. ed. Sofia, Moscow: Pensoft Publishers, 2006. 508 p.

TRILLES, J. P. Les Cymothoidae (Isopoda, Flabellifera) des cotes francaises. II. Les Anilocridae Schioedte et Meinert, 1881. Genres Anilocra Leach, 1818, et Nerocila Leach, 1818. Bulletin du Muséum National d'Histoire Naturelle, Zoologie, Paris, v. 200, p. 347-378, 1975.

WILSON, G. D. F. Global diversity of Isopod crustaceans (Crustacea; Isopoda) in freshwater. Hydrobiologia, Brussels, v. 595, p. 231-240, 2008.

YOUNES, A. M.; ELDIN, A. I. N.; ELLATIF, M. A. A. A contribution of crustacean isopodoa, bacterial infections and physicochemical parameters in mass mortalities among fishes in Lake Qarun. Research Journal of Pharmaceutical, Biological and Chemical Sciences, New Delhi, v. 7, n. 2, p. 1906-1911, 2016. 